\title{
O Coaching como Ferramenta na Formação de Liderança nas Organizações Comerciais: Estudo de Caso em uma Empresa de Juazeiro do Norte
}

\author{
Matheus de Medeiros Luna ${ }^{1}$; José Leandro Almeida Neto ${ }^{2}$; Thércia Lucena Grangeiro Maranhão ${ }^{3}$; \\ Franscisca Laudeci Martins Souza ${ }^{4}$
}

\begin{abstract}
Resumo: O presente trabalho tem por objetivo conhecer a importância do Coaching como ferramenta no desenvolvimento da liderança, bem como a aplicação de processos de Coaching no âmbito organizacional e como a liderança e o Coaching estão interligados. Buscando entender como esses procedimentos podem auxilia no desenvolvimento de competências das organizações. Será feito um estudo de caso em uma dada empresa na cidade de Juazeiro do Norte, composta por 26 funcionários. A empresa já existiu há 10 anos, retornando no mês de outubro de 2012. Tendo por volta de três anos e meio de existência. Nessa empresa existem práticas de treinamento para os gerentes, tanto on-line quanto presenciais, a fim de desenvolver os gerentes para que possa treinar a equipe. Quanto às bases lógicas de investigação, método da pesquisa foi hipotético dedutivo. Será aplicado um questionário para os colaboradores e entrevista para o gestor. Ao realizar o trabalho foram utilizadas pesquisas bibliográficas, textos em sites e artigos científicos. Ao término do trabalho ficou comprovado que o Coaching é considerada ferramenta de auxílio de liderança, potencializando assim as habilidades e maximização de resultados.
\end{abstract}

Palavras Chave: Coaching. Gestão de pessoas. Liderança.

\section{Coaching as a Tool in the Leadership Training in Business Organizations: A Case Study in a Juazeiro do Norte Company}

\begin{abstract}
The present work aims to know the importance of Coaching as a tool in the development of leadership, as well as the application of Coaching processes in the organizational scope and how leadership and coaching are interconnected. Seeking to understand how these procedures can help in the development of the competences of the organizations. A case study will be done at a company in the city of Juazeiro do Norte, made up of 26 employees. The company has existed for 10 years, returning in the month of October 2012. Having been around for three and a half years. In this company there are training practices for managers, both online and in person, in order to develop managers so that they can train the team. There is a platform to develop the collaborator through online courses, where several tracks are included, such as, integration of new collaborators, trail of learning and growth, program of participation of results, among others. Regarding the logical bases of investigation, the research method was hypothetical deductive. A questionnaire was applied to the employees and interviewed to the manager. In carrying out the work, bibliographical research, texts on websites and scientific articles were used. At the end of the work it was proven that Coaching really acts as a tool of leadership assistance, thus enhancing skills and maximizing results.
\end{abstract}

Keywords: Coaching. People management. Leadership.

\footnotetext{
${ }^{1}$ Graduando do Curso de Administração do Centro Universitário Doutor Leão Sampaio/UNILEÃO- matheusmedeiros1994@ hotmail.com.

${ }^{2}$ Professor do curso de Administração . Coordenador dos cursos de Gestão de RH e Gestão Comercial da UNILEÃO. Mestrando do curso de Desenvolvimento Regional da UFCA. leandro@leaosampaio.edu.br.

${ }^{3}$ Professora do curso de psicologia e gestão de RH da UNILEÃO- thercia@leaosamapio.edu.br

${ }^{4}$ Doutora em Educação. Professora do Mestrado em Desenvolvimento Regional Sustentável da Universidade Federal do Cariri - UFCA e do Departamento de Economia da Universidade Regional do Cariri - URCA. E-mail: laudecimartins@yahoo.com.br.
} 


\section{Introdução}

O ser humano está em constante processo de mudança e evolução consigo mesmo, buscando se aperfeiçoar e estimular cada vez mais, a fim de motivar, treinar e desenvolver para se adaptar a um novo modelo de organização. Isso se deve principalmente a globalização mundial acompanhada de uma maior competitividade.

Diante do mercado cada vez mais dinâmico, as organizações precisam de líderes capacitados e aptos no desenvolvimento de suas habilidades e competências dentro da empresa. Nesse sentido surge o Coaching. Uma ferramenta muito utilizada para o desenvolvimento pessoal e profissional de lideranças nas organizações para melhorar o desempenho destas.

Bom relacionamento interpessoal, liderança e flexibilidade são exemplos de características cada vez mais apreciadas por gestores de empresas, que resultará em grande vantagem competitiva em relação aos concorrentes.

Um dos grandes problemas enfrentados no mercado, se dá pela necessidade de desenvolvimento constante da liderança, tendo em vista que não é uma tarefa simples. Ao longo dos tempos, o conceito de liderança vem sendo adaptado e passado por várias mudanças. Em épocas remotas o líder era visto como a pessoa que simplesmente conduzia os processos como qualquer outro colaborador, mas tarde, sua essência é aprimorada pela necessidade de algo inovador no mercado para fazer o diferencial.

A essência do Coaching está em fornecer suporte para que o indivíduo aprimore, se transforme e evolua, tendo em vista que os indivíduos possuem habilidades e competências que, se estimuladas, propiciam grandes feitos, seja no seu desempenho pessoal ou profissional.

O presente trabalho objetiva: apresentar o Coaching como ferramenta importante no desenvolvimento da liderança em uma organização comercial na cidade de Juazeiro do Norte a partir de um estudo de caso.

Assim, soma-se relevante para alcançar esse objetivo, alguns objetivos específicos, tais como: identificar o principal papel do Coaching nas organizações comerciais; realizar estudo de caso em empresa comercial de Juazeiro do Norte; verificar sua importância no desenvolvimento da liderança; identificar os reflexos da liderança Coaching e avanço dos resultados da empresa pesquisada; sondar os efeitos do Coaching no crescimento e desenvolvimento de habilidades dos profissionais.

Diante do que foi elencado, faz-se importante, extrair uma conclusão sobre alguns fatores, tais como: crescimento dos profissionais envolvidos; eficiência nos processos organizacionais por eles geridos e melhoria dos resultados; melhor produtividade nos setores da empresa; avanço no alcance de 
metas e resultados; aperfeiçoamento da liderança e gestão por parte dos coordenadores e líderes. Os quais caracterizam as hipóteses deste trabalho.

Para a coleta dos dados será aplicado um questionário aos colaboradores e uma entrevista com o gestor da empresa. Com a finalidade de identificar a eficácia das ferramentas de Coaching no que diz respeito a liderança. Os quais, posteriormente, serão digitados, tabulados e passados por uma análise interpretativa.

Associado ao conceito de líder, o Coaching está diretamente ligado ao relacionamento de liderança em equipe desenvolvendo técnicas e métodos para atingir as metas da organização e sucesso profissional e pessoal do liderado.

Uma das ferramentas mais utilizadas atualmente para o desenvolvimento da liderança é o Coaching.

Dessa forma, cada líder age e se associa de maneira pessoal com seus subordinados imediatos, podendo estes, assumir comportamentos adversos em função da sua atuação. Se positivo, esses comportamentos implicarão em bons resultados e farão com que a empresa se torne coesa.

Tendo em vista que, diante do cenário atual, de grandes desafios, as organizações precisam potencializar suas habilidades e de adaptar aos processos de mudança e das novas exigências do mundo globalizado.

Diante disso, justifica-se este trabalho, pela necessidade de se saber como o Coaching é utilizado para desenvolver a liderança em organizações comerciais? Bem como, até que ponto o Coaching contribui nos resultados das organizações? e saber a influência que o mesmo possui entre líderes e liderados. Tendo em vista que uma boa aplicação do Coaching trará ótimos resultados, melhorando cada vez mais a performance e evolução das empresas, motivando e encorajando a equipe.

$\mathrm{O}$ tema em questão refere-se a um estudo sobre essa ferramenta que é de grande importância para um bom desempenho das organizações e colaboradores no âmbito pessoal e profissional. A fim de que possa contribuir para leitores, pesquisadores e acadêmicos que desejam aplicar ou pesquisar sobre as relações e vantagens do Coaching como mediador de desempenho.

\section{O Coaching e suas definições}

Existem diversas definições sobre Coaching. "O Coaching é um tipo de relacionamento no qual o Coach se compromete a apoiar e ajudar o aprendiz para que este possa atingir determinado resultado ou seguir determinado caminho." (CHIAVENATO, 2002, p. 41)

Segundo Chiavenato (2002, p. 40) "O Coaching envolve o compromisso de apoiar e de ajudar 
as pessoas a realizar metas desafiadoras que estão colocadas no médio ou no longo prazo".

Souza (2007) afirma que em sua essência o Coaching não é um processo novo, embora ainda seja pouco disseminado nas organizações. Devido, talvez ter sido transposto do esporte ou do lar para as empresas sem as adaptações que lhes seriam precisas.

$\mathrm{Na}$ visão do autor, faz-se necessário compreender o processo do Coaching para não se desvirtuar do objetivo e da verdadeira intenção do Coaching. Segundo uma metáfora realizada pelo mesmo autor, a palavra Coaching significa um veículo para transportar pessoas de valor, considerando sua atual posição e onde querem chegar. Ou seja, isso significa ajudar as pessoas a enxergarem além do posicionamento em que se encontram hoje para torna-se o que querem ser no amanhã, aumentando seus níveis de competência, seu desempenho e suas crenças. A fim de atingir suas metas.

Portanto, seguindo essa linha de pensamento, Alves (2013) afirma que planejar o objetivo não é suficiente, ou seja, é importante também que se faça todo um planejamento de como chegar a este objetivo. Sendo necessário, para isso, identificar as habilidades e competências que serão precisas e farão algum tipo de diferencial na busca dos objetivos para a carreira.

É sabido que o ser humano possui características que lhes são inatas, no entanto, nem todas as pessoas ou profissionais sabem como adquirir ou estimular tais características. Nesse sentido, acabam por perder boas oportunidades profissionais e perdem a chance de atingir o sucesso. Por essa razão, está aumentando cada vez mais no ramo empresarial um mercado que ainda é pouco disseminado e pouco conhecido, embora tenha ganhado destaque em alguns países, por ser procurado cada vez mais por pessoas que querem aprimorar o desempenho em suas carreiras. Essa área é chamada de Coaching.

Souza (2007) acrescenta que se lê e se ouve falar bastante acerca dos conceitos e explicações desse termo, os quais define, o Coaching como o processo; o Coach a pessoa quem dirige o processo; e o Coachee como a pessoa que se submeteu ao processo ou que ainda é favorecida por ele.

Já na perspectiva de Chiavenato (2002) o Coaching se constitui um tipo de relacionamento no qual o Coach apóia e ajuda o aprendiz para que este possa atingir um determinado resultado. E ainda afirma que tanto o Coach quanto o cliente saem beneficiados no sentido de que o Coaching é um relacionamento que produz novas competências, ou seja, as experiências adquiridas com cada cliente são únicas, produzindo novos conhecimentos e novas experiências para ambas as partes. Nesse sentido afirma que o Coaching é um relacionamento que envolve no mínimo duas pessoas - o Coach e o aprendiz. E que o mesmo se espelha em uma ligação que estimula e impulsiona talentos, estimulando suas competências e habilidades. Ou seja, o Coach orienta, lidera, guia, treina, aconselha, desenvolve, estimula, impulsiona o aprendiz. Seguindo essa linha de pensamento o autor afirma que o Coaching vai muito além de um simples treinamento, aconselhamento, encarreiramento ou de liderança. Salienta também que o Coach fica com a pessoa até o ponto em que ela consegue atingir o resultado esperado 
ou até o ponto em que ela ainda almeja.

Souza (2007) afirma que devido a grande quantidade de recursos educacionais existentes no mercado a maior parte dos treinamentos são realizados nos postos de trabalho, o que ele chama de onthejob, e afirma que provavelmente continuará assim. Ainda acrescenta que mesmo gerentes e diretores, que ocupam os níveis mais altos da estrutura organizacional, agregam mais conhecimento observando os outros e com os erros.

"Essa constatação não é a única justificativa para o Coaching, mas só ela já seria suficiente para admitirmos a necessidade de se debruçar na cultura do Coaching." (SOUZA, 2007, p. 37)

Diante disso, o mesmo autor relata sobre as discussões que por ele são vistas nas organizações a cerca do verdadeiro e mais imediato papel da área de Recursos Humanos, os quais sempre cita a tarefa de desenvolver líderes. Ou seja, é essencial que haja uma boa preparação dos gestores no intuito de se familiarizarem quando se tratar de gestão de pessoas, para que consigam com êxito enfrentar diferentes situações, pessoas, resultados e reações que aparecem diariamente. No entanto, ressalta a importância de bons lideres que sabem trabalhar em equipe, desfrutando e beneficiando suas potencialidades, com resultados, e sem ter que pagar um alto preço por isso. O fato é que é de suma importância ter lideres focados na evolução e desenvolvimento das pessoas para que possa refletir nos resultados e na performance, cabendo em toda e qualquer tipo de empresa, nacionalidade e tamanho.

Nesse sentido, completa com algumas indagações acerca do por que do Coaching. O qual afirma que se trata puramente de estratégia e que sua utilização não se dá pelo simples fato de está na moda fazer o bem ou algo similar; Como a mudança é inevitável e a todo o momento muda plenamente as condições de vida e de todo um negócio, precisa-se ter algo que apoie as pessoas a se adaptarem rapidamente; é importante reforçar que tecnologia e dinheiro não são mais bloqueios; $\mathrm{O}$ Coaching é importante para ter os funcionários comprometidos com os resultados e clientes afim de valorizar seus resultados de forma positiva; Porque não temos mais tempo para esperar que os funcionários se auto-desenvolvam. Coaching é uma tecnologia de ponta no que diz respeito ao desenvolvimento de pessoas; No cenário atual a liderança está inserida em um contexto novo, a responsabilidade e o que se pode ganhar com uma fundamentada atuação de liderança muitas vezes é imensurável. É mais fácil pensar no que se perde e no que se deixa de ganhar com hábitos inadequados de liderança porque são fatos do dia a dia.

\section{Design do Processo de Coaching}

Gramigna (2007) afirma que para atender a busca de técnicas que dizem respeito a liderança 
de pessoas, nos anos de 1990, surgiu a gestão por competências, a qual acrescenta valor aos diferentes tipos de negócios que existem no mercado brasileiro. Sendo assim, Gramigna (2007, p. 43) define por gestão de competências; "Um conjunto de ferramentas, instrumentos e processos metodológicos voltados para a gestão estratégica de pessoas".

Contudo, diante dos novos desafios da nova economia, com a competição cada vez mais acirrada e o mercado globalizado, Gramigna (2007) indaga que três desafios se fazem presentes: A adesão de tecnologias inovadoras que permitam pleitear de igual para igual com os concorrentes; $\mathrm{O}$ alinhamento de processos internos para adiantar e apontar qualidade em produtos e serviços; $\mathrm{O}$ acolhimento de um modelo assertivo de gestão de pessoas capaz de identificar, desenvolver e reter talentos como predominante fonte de capital.

Souza (2007) afirma que a integração estratégica do Coaching e da gestão por competências se completam de forma altamente produtiva. Ou seja, quanto maior for a quantidade de colaboradores que a organização ou o líder possuir, mais será imprescindível uma base e estrutura para que haja um levantamentos, entendimento e sistematização das informações.

Ressalta ainda que Gestão por competências é completamente conduzido para pessoas, e afirma desconhecer qualquer outro programa deste tipo, com uma direção tão adequada e pertinente para distinguir e gerir informações estratégicas de todos os funcionários da empresa.

"A gestão por competências empresta uma qualitativa estrutura necessária ao trabalho dos líderes, que como Coaches se valem destas facilidades para implantar seu processo de gestão". (SOUZA, 2007, p. 91)

De acordo com Gramigna (2007) pessoas que investem no auto desenvolvimento possuem maiores possibilidades de sucesso no que diz respeito a carreira, sendo assim, favorecem seu processo de mudança e avanço. Além do ganho próprio ou pessoal, o tipo de profissional que idealiza essa competência com precaução são notadas pela direção como comprometidos, responsáveis e envoltos no atual contexto de exigências, sendo percebidos de forma positiva.

\section{Coaching e Liderança}

Cavalcanti, et al. (2009) afirma que não é algo simples definir o conceito de liderança e possivelmente seja mais fácil identificar quem possui do que defini-la. No entanto, a definição mais provável seria a capacidade de influenciar pessoas ou grupos de pessoas, sendo que esse conceito vem passando por transformações que são influenciadas pelas questões culturais, ambientais, sociais dos pesquisadores. 
"Muitas pessoas gostariam de ser lideradas por um líder. Gerenciar é controlar, manejar ou manipular. Liderar é guiar, influenciar ou persuadir. Você gerencia coisas - sistemas, processos e tecnologia. Você lidera pessoas." (CHIAVENATO, 2002, p.123)

Nesse sentido, Dutra (2009) acrescenta que as pessoas são vistas pela organização como insumos, isto é, como um recurso que pode ser administrado. Embora haja grandes transformações no que diz respeito a organização da produção, por princípios que se referem a gestão de pessoas em rotinas gerenciais têm ainda como primordial fio condutor o controle sobre as pessoas.

Seguindo essa linha de pensamento, Bergamini (2002) faz um comparativo onde explica que o interesse pela liderança é tão antigo quanto o próprio homem e que bastou haver o encontro entre duas pessoas, em que uma delas seria solicitada a interpretar a situação que estaria acontecendo naquele momento, a fim de impulsionar um rumo a ser seguido. Afirma ainda que há a possibilidade de dizer que a busca de respostas para enfrentar os desafios que são propostos pela convivência humana data de tempos remotos. O que permite observar que a liderança tenha surgido a partir do momento que o próprio homem precisou estruturar o mundo em que vivia.

O Coaching é o refinamento da liderança, é o que se tem de mais poderoso para dar significância ao colaborador, comprometendo-o de vez com seus próprios resultados e com os da empresa. Por isso, a evolução para o foco da pessoa, porque é como se tudo estivesse sendo visto pelo ponto de vista dela. É puramente uma questão de empatia. (SOUZA, 2007, p. 93)

Nesse sentido Cavalcanti, et al. (2009), acrescenta que o tema liderança tem proporcionado um grande ressalto nas discussões em congressos, nas empresas, palestras, dentro das salas de aula e em qualquer momento no qual haja um encontro a fim de debater sobre os destinos dos negócios, em um mercado cada vez mais competidor e em constantes transformações e adaptações. Entretanto, o mesmo autor acrescenta que diante dos desafios atuais, não existe incerteza de que vivemos em uma era de rupturas e mudanças.

É importante ressaltar que essas mudanças, segundo Alves (2013), que ocorrem nos mercados globalizados estão ocasionando um efeito de cuidados dos profissionais no que diz respeito as suas carreiras. Isto é, estas mudanças firmam novas oportunidades para os profissionais que estejam preparados para tal, em contrapartida, também estabelecem muitos desafios para os profissionais que não estão preparados para estas mudanças.

O ingresso no novo milênio tem levado pessoas e organizações a refletir e a buscar o verdadeiro significado do papel que representam, Para as organizações, ampliam-se a percepção de um novo papel a desempenhar e a necessidade de buscar alinhamento e integração entre o meio ambiental, social e o mundo dos negócios. Para as pessoas, 
amplia-se a necessidade não só de encontrar identificação e satisfação com seu trabalho, como também contribuir para um bem maior. (CAVALCANTI, et al, 2009, p.17)

Diante disso, Gramigna (2007) concorda com o pensamento do autor acima, e acrescenta que hoje, mais do que nunca, é preciso potencializar os resultados através do exercício sinérgico e revertido para resultados.

\section{Desenvolvimento de Lideranças}

Souza (2007) divide o processo de Coaching em quatro fases para detalhar o seu relacionamento, afim de que cada uma delas possa descrever e ilustrar ferramentas poderosas que facilitam a liderança: Determinar uma relação de confiança; Ter entendimento da situação; Traçar metas; ter um bom planejamento: ações e contingências.

Nessa mesma linha de pensamento, o autor ainda ressalta que em alguns casos não há uma sequência a seguir e também não se trata de uma caixa fechada, ou um modelo que seja preciso seguir exatamente como o apresentado. Servirá apenas para a orientação e para que, sempre que achar que os resultados forem satisfatórios, possa repeti-lo, já que os passos já estão bem definidos.

Segundo o mesmo autor uma dúvida muito comum diz respeito a diferença entre autocrático e democrático e ressalta que existe uma certa confusão nesses termos, e acaba confundindo a performance de atuação dos líderes.

Tradicionalmente a liderança é classificada em três tipos. São eles: autocrática, democrática e liberal.

"Estilos de liderança é o padrão recorrente de comportamento exibido pelo líder" (CHIAVENATO, 2005, p. 186)".

Podem ser encontrados diversos tipos de liderança. Chiavenato $(2005$, p. 187) trás três formas de liderança divididas em quatro estágios, conforme apresentado no Quadro 1.

Quadro 1: Os três estilos de liderança 


\begin{tabular}{|c|c|c|c|}
\hline ASPECTOS & $\begin{array}{l}\text { LIDERANÇA } \\
\text { AUTOCRÁTICA }\end{array}$ & $\begin{array}{c}\text { LIDERANÇA } \\
\text { DEMOCRÁTICA }\end{array}$ & $\begin{array}{l}\text { LIDERANÇA } \\
\text { LIBERAL }\end{array}$ \\
\hline Tomada de decisões & $\begin{array}{l}\text { Apenas o líder decide e fixa } \\
\text { as diretrizes, sem qualquer } \\
\text { participação do grupo. }\end{array}$ & $\begin{array}{l}\text { Total liberdade para a } \\
\text { tomada de decisões } \\
\text { grupais ou individuais, } \\
\text { com participação mínima } \\
\text { do líder. }\end{array}$ & $\begin{array}{l}\text { As diretrizes são } \\
\text { debatidas e decididas } \\
\text { pelo grupo que é } \\
\text { estimulado e assistido } \\
\text { pelo líder. }\end{array}$ \\
\hline $\begin{array}{l}\text { Programação dos } \\
\text { trabalhos }\end{array}$ & $\begin{array}{l}\text { O líder determina } \\
\text { providências para a execução } \\
\text { das tarefas, uma por vez, na } \\
\text { medida em que são } \\
\text { necessárias e de modo } \\
\text { imprevisível para o grupo. }\end{array}$ & $\begin{array}{l}\text { A participação do líder } \\
\text { no debate é limitada, } \\
\text { apresentando apenas } \\
\text { alternativas ao grupo, } \\
\text { esclarecendo que poderia } \\
\text { fornecer informações } \\
\text { desde que solicitadas. }\end{array}$ & $\begin{array}{l}\text { O próprio grupo esboça } \\
\text { providências e técnicas } \\
\text { para atingir o alvo com o } \\
\text { aconselhamento técnico } \\
\text { do líder. As tarefas } \\
\text { ganham novos contornos } \\
\text { com os debates. }\end{array}$ \\
\hline Divisão do trabalho & $\begin{array}{l}\text { O líder determina qual a } \\
\text { tarefa que cada um deverá } \\
\text { executar e qual seu } \\
\text { companheiro de trabalho. }\end{array}$ & $\begin{array}{l}\text { Tanto a divisão das } \\
\text { tarefas como a escolha } \\
\text { dos colegas ficam por } \\
\text { conta do grupo. Absoluta } \\
\text { falta de participação do } \\
\text { líder. }\end{array}$ & $\begin{array}{l}\text { A divisão das tarefas fica } \\
\text { a critério do grupo e cada } \\
\text { membro tem liberdade de } \\
\text { escolher seus próprios } \\
\text { colegas. }\end{array}$ \\
\hline $\begin{array}{l}\text { Participação do } \\
\text { líder }\end{array}$ & $\begin{array}{l}\text { O líder é pessoal e dominador } \\
\text { nos elogios e nas críticas ao } \\
\text { trabalho de cada um. }\end{array}$ & $\begin{array}{l}\text { O líder não faz nenhuma } \\
\text { tentativa de avaliar ou } \\
\text { regular o curso das } \\
\text { coisas. Faz apenas } \\
\text { comentários } \\
\text { perguntado. }\end{array}$ & $\begin{array}{l}\text { O líder procura ser um } \\
\text { membro normal do } \\
\text { grupo. E objetivo e } \\
\text { estimula com fatos, } \\
\text { elogios ou críticas. }\end{array}$ \\
\hline
\end{tabular}

Fonte: Chiavenato (2005, p. 187)

O mesmo mostra a importância do líder nos variados tipo de liderança, sendo que este desempenha papel de auxiliar na maximização do resultado, treinamento e capacitação dos colaboradores, como também é visto como uma figura de respeito.

\section{Metodologia}

Encontram-se apresentados abaixo alguns aspectos metodológicos que serão fundamentais para o desenvolvimento deste estudo, os quais contribuirão para o alcance eficaz dos objetivos propostos, e para uma maior qualidade da investigação.

A pesquisa caracterizou-se como bibliográfica. Para Gil (2010) pesquisa bibliográfica é concluída com base em conteúdo já publicado. Este tipo de pesquisa inclui livros, revistas, material impresso, jornais, teses, dissertações e anais de eventos. Contudo, após o aparecimento de novos formatos de informações, estas pesquisas passaram a agregar outros tipos de fontes, como discos, fitas 
magnéticas, $\mathrm{CD}^{\prime} \mathrm{S}$, e material disponível na internet.

Praticamente toda pesquisa acadêmica em sua essência em algum dado momento a realização de trabalho que pode ser definido como pesquisa bibliográfica.

A principal vantagem desse tipo de pesquisa se dá pelo fato de permitir ao pesquisador a cobertura de uma gama de fenômenos muito maior do que aquela que poderia se pesquisar diretamente.

Quanto aos objetivos, caracteriza-se do tipo exploratório com abordagem qualitativa, que segundo Strauss e Corbin (2008) a pesquisa qualitativa se refere a qualquer tipo de pesquisa que obtenha resultados não alcançados, por meio de procedimentos estatísticos ou outros meios de quantificação. E quantitativa, que segundo Oliveira (2008) esse método caracteriza-se em quantificar dados obtidos por meio de informações obtidas através de questionários, entrevistas, observações, e etc.

A referida pesquisa será de natureza aplicada, a qual, segundo Vergara (2009) esse tipo de pesquisa é motivada através da necessidade de resolução de problemas, sendo eles imediatos ou não.

No que diz respeito aos objetivos, a pesquisa caracterizou-se como descritiva, pois, de acordo com Cervo e Bervian (2002) a pesquisa descritiva tem como objetivo registrar, bem como fazer uma análise dos fatos sem alterá-los. Segundo os mesmos, esse tipo de pesquisa procura entender as várias situações e relações que ocorrem na vida social, econômica, política e outros aspectos relacionados ao comportamento humano. Desenvolvem-se essencialmente nas ciências humanas e sociais dando ênfase a problemas que merecem ser estudadas e cujo registro não consta em documentos. E exploratória, a qual, segundo Cervo e Bervian (2002) o estudo exploratório, designado por alguns autores como pesquisa quase científica ou não científica é geralmente, o pontapé inicial no procedimento de pesquisa pela experiência e um auxilio acompanhado da formulação de hipóteses significativas para consequentes pesquisas.

O procedimento utilizado foi estudo de caso, o qual, segundo Gil (2009) se caracterizam pelo grande consumo de tempo e energia intelectual, bem como, energia física dos pesquisadores. Onde também foi feita uma análise de conteúdo. A qual, segundo Bardin

Descrever a história da análise de conteúdo é essencialmente referenciar as diligências que nos Estados Unidos marcaram o desenvolvimento de um instrumento de análise de comunicações é seguir passo a passo o crescimento quantitativo e a diversificação qualitativa dos estudos empíricos apoiados na utilização de uma das técnicas classificadas sob a designação genérica de análise de conteúdo; é observar a posteriori os aperfeiçoamentos materiais e as aplicações abusivas de uma pratica que funciona há mais de meio século (BARDIN, 2009, p.15).

A coleta de dados efetuada através de um questionário para os colaboradores da empresa com 
perguntas semi-estruturadas e abertas. Segundo Cervo e Bervian (2002) o questionário é o meio mais utilizado para a coleta de dados, devido a possibilidade de medir com grande êxito o que se espera. É necessário identificar as questões mais importantes a serem abordadas e que tem a necessidade de ser conhecidas, relacionadas com os objetivos. Segundo o mesmo, se faz necessário que todo questionário tenha uma natureza impessoal, a fim de que se tenha uma avaliação uniforme em uma dada situação. E entrevista para o gestor.

Neste estudo será considerado a utilização do Coaching como ferramenta na formação de liderança em uma empresa comercial no setor varejista na cidade de Juazeiro do Norte.

Esta pesquisa será realizada em uma empresa que utiliza técnicas de Coaching como ferramenta de melhoria da sua performance, localizada em Juazeiro do Norte. Os participantes selecionados dentro de um grupo são de indivíduos que convivem com o assunto a ser discutido, que tenham domínio e aplicação do mesmo em suas respectivas organizações.

Os sujeitos da pesquisa foram os colaboradores e gestor da empresa. Foi solicitado o pedido de autorização para os entrevistados através do TCLE que depois de lido foi entregue e devidamente assinado.

Para efeito de coleta de dados foi aplicado um questionário contendo 09 (nove) questões, onde, foi aplicada aos colaboradores e uma entrevista feita com o gestor, de acordo com a disponibilidade e com prévia autorização.

A análise dos dados foi feita de forma interpretativa, uma vez que a pesquisa é qualitativa. Os dados obtidos em virtude dos questionários que foram aplicados, interpretados e analisados de forma imparcial e criteriosa por parte do pesquisador.

Inicialmente, o presente artigo de pesquisa foi submetido ao Comitê de Ética em Pesquisa (CEP) do Centro Universitário Doutor Leão Sampaio.

Após a aprovação do Comitê de Ética faz-se necessário contatar à organização pretendida para a realização da investigação e estabelecer um primeiro contato com os responsáveis pelos departamentos de gerência.

Cada participante da pesquisa foi informado sobre os objetivos e metodologia utilizada na mesma, garantindo o sigilo, a confidencialidade das informações fornecidas, assim como o direito de recusar-se a participar ou solicitar sua exclusão a qualquer momento do estudo, sem ter prejuízos de qualquer natureza.

Aos gerentes que aceitaram participar do estudo, foi entregue duas cópias do Termo de Consentimento Livre e Esclarecido (TCLE). Esses ficaram com uma via assinada pelo pesquisador e devolveu a outra, firmando assim sua aceitação em participar da pesquisa, e também autorizando a divulgação e publicação dos resultados. 
Essa pesquisa respeitou os aspectos éticos embasados na Resolução 510/16 do Conselho Nacional de Saúde, que normatiza as pesquisas na área de ciências humanas e sociais, onde, de acordo com a mesma, a resolução 510/16, considera que a ética é uma construção humana, logo histórica, social e cultural. Bem como, a ética em pesquisa implica o respeito pela dignidade humana e pela especial proteção devida aos participantes das pesquisas científicas que envolvem seres humanos, considerando-se que a ética do pesquisador demanda ação consciente e livre do participante. Além disso, essa resolução compete ainda, que a pesquisa em ciências humanas e sociais requer respeito e garantia do pleno exercício dos direitos dos participantes.

No que diz respeito aos riscos inerentes a essa pesquisa, compreende algum tipo de constrangimento ou desconforto por parte dos entrevistados, com relação a responder perguntas encaradas como de sigilo, que de alguma forma possa trazer um impacto negativo para o mesmo ou para a empresa. A fim de minimizar tal impacto cada participante da pesquisa será convidado a preencher cada questionário anonimamente. Todos os dados fornecidos foram de natureza confidencial e o anonimato dos mesmos serão resguardados.

Visando benefícios, este projeto e o estudo que o constituem podem instigar proveitos para os sujeitos participantes, contribuindo assim, para melhorias da sua performance pessoal profissional, bem como o desempenho da organização como um todo.

\section{Análise e Discussão dos Resultados}

\section{Questionário Aplicado aos Colaboradores}

Foi aplicado um questionário aos colaboradores da respectiva loja, os quais responderam 09 (nove) perguntas abertas no que diz respeito ao Coaching como ferramenta de liderança. Observou-se que a faixa etária dos entrevistados é de 21 a 30 anos e suas funções variam entre; assistente administrativo, atendente de serviços ao cliente, assistente de vendas, calçados e acessórios, prevenção de perdas, estoque. Em primeira instância procurou-se investigar qual o grau de importância do seu trabalho, onde todos destacaram de muita importância por questões de satisfação pessoal, conhecimento, atingir as metas da empresa e etc.

Em seguida, foram questionados sobre o treinamento que recebem do seu gerente, onde, foi definido por unanimidade um excelente e alto nível de treinamento, os quais relataram que o gerenciamento é muito elevado e sempre se preocupa em trabalhar a motivação, habilidade dos colaboradores e resultados a serem atingidos. Partindo do princípio de que a empresa cresce junto com 
o colaborador, questionou-se sobre suas possibilidades de crescimento dentro da empresa, nesse sentido, todos os colaboradores responderam que a empresa proporciona um alto nível de crescimento, o qual depende exclusivamente do desempenho e eficiência de cada um.

Foi perguntado também a cerca do conhecimento de cada um sobre o conceito ou significado do Coaching, onde praticamente todos, definiram o real significado deste na sua essência, e posteriormente suas percepções de Coaching que são utilizadas na empresa, a qual foi destacada constantes treinamentos, que são trabalhados motivação, quebra de barreiras, aumento da autoconfiança, liderança e outros. Quando questionados sobre essas técnicas terem contribuído para o seu desenvolvimento pessoal, $100 \%$ dos entrevistados disseram que contribuiu muito e refletiu em resultados rápidos, eficientes e duradouros, bem como, as relações pessoais e profissionais. Nesse sentido, questionou-se:

Quadro 1: Grau é o grau de importância do seu trabalho.

\begin{tabular}{|c|c|c|c|}
\hline Colaboradores & Resposta & Recorte & Categoria \\
\hline $\begin{array}{c}\text { Pesquisado } \\
01\end{array}$ & $\begin{array}{l}\text { Meu trabalho é muito importante, pois } \\
\text { através dele obtenho conhecimento } \\
\text { necessário para meu crescimento. A } \\
\text { importância do meu trabalho vem } \\
\text { também do desempenho e dedicação no } \\
\text { qual exerço. }\end{array}$ & $\begin{array}{l}\text { É importante porque } \\
\text { através dele obtenho } \\
\text { conhecimento para } \\
\text { meu crescimento. }\end{array}$ & Crescimento \\
\hline $\begin{array}{l}\text { Pesquisado } \\
02\end{array}$ & $\begin{array}{l}\text { Vejo como um grau de satisfação pelo } \\
\text { qual me sinto realizado e comprometido } \\
\text { no que faço, sempre buscando mostrar o } \\
\text { meu melhor. }\end{array}$ & $\begin{array}{l}\text { Realização pessoal e } \\
\text { profissional a fim de } \\
\text { se doar ao máximo } \\
\text { para atingir os } \\
\text { objetivos da empresa }\end{array}$ & $\begin{array}{c}\text { Realização e } \\
\text { Satisfação }\end{array}$ \\
\hline $\begin{array}{c}\text { Pesquisado } \\
03\end{array}$ & $\begin{array}{l}\text { Extrema importância, pois trabalho em } \\
\text { uma empresa que depende de mim para } \\
\text { atingir suas metas, ao mesmo tempo ela } \\
\text { se preocupa em desenvolver } \\
\text { profissionais e alavancar carreiras. }\end{array}$ & $\begin{array}{l}\text { Extrema importância, } \\
\text { pois a empresa } \\
\text { depende do meu } \\
\text { comprometimento } \\
\text { para atingir os seus } \\
\text { resultados }\end{array}$ & $\begin{array}{l}\text { Alavancar } \\
\text { carreiras }\end{array}$ \\
\hline $\begin{array}{c}\text { Pesquisado } \\
03\end{array}$ & $\begin{array}{l}\text { Muito importante. Tanto pelo fato de } \\
\text { que preciso do dinheiro desse trabalho, } \\
\text { como também por eu ter a chance de } \\
\text { crescer profissionalmente nessa } \\
\text { empresa. }\end{array}$ & $\begin{array}{l}\text { O grau de } \\
\text { importância está } \\
\text { ligado a necessidade } \\
\text { financeira, bem } \\
\text { como, de crescimento } \\
\text { profissional. }\end{array}$ & Crescimento \\
\hline $\begin{array}{c}\text { Pesquisado } \\
05\end{array}$ & $\begin{array}{l}\text { Extrema importância. A cada dia sinto } \\
\text { vontade de aprender e crescer junto com } \\
\text { a empresa, pois, sei que seus objetivos } \\
\text { dependem do meu esforço. }\end{array}$ & $\begin{array}{l}\text { Os resultados da } \\
\text { empresa dependem } \\
\text { do meu esforço e } \\
\text { dedicação. }\end{array}$ & Esforço \\
\hline $\begin{array}{c}\text { Pesquisado } \\
06\end{array}$ & $\begin{array}{l}\text { Alto, pois faço parte do pessoal, } \\
\text { contribuo para uma boa administração } \\
\text { na minha área, com empenho para que } \\
\text { assim a empresa tenha bons resultados. }\end{array}$ & $\begin{array}{l}\text { Grande importância, } \\
\text { pois os resultados da } \\
\text { empresa dependem da } \\
\text { minha competência. }\end{array}$ & Resultados \\
\hline
\end{tabular}


Id on Line Revista Multidisciplinar e de Psicoloqia

Id on Line Multidisciplinary and Psycology Journal

\begin{tabular}{|c|c|c|c|}
\hline $\begin{array}{l}\text { Pesquisado } \\
07\end{array}$ & $\begin{array}{l}\text { Considero muito importante, pois } \\
\text { contribuo com o financeiro da empresa. }\end{array}$ & $\begin{array}{lr}\text { Grande importância, } \\
\text { devido se tratar } \\
\text { principalmente } \\
\text { financeiro. }\end{array}$ & Contribuição \\
\hline $\begin{array}{c}\text { Pesquisado } \\
08\end{array}$ & $\begin{array}{l}\text { Grande importância. Pois, trabalho para } \\
\text { reduzir as perdas e com isso aumentar o } \\
\text { lucro da empresa. }\end{array}$ & $\begin{array}{l}\text { É importante devido } \\
\text { se tratar de um setor } \\
\text { importante que está } \\
\text { diretamente ligado ao } \\
\text { lucro da empresa. }\end{array}$ & Lucro \\
\hline $\begin{array}{c}\text { Pesquisado } \\
09\end{array}$ & $\begin{array}{l}\text { Alto, pois é de onde vem o meu sustento } \\
\text { e sei que ela também precisa de mim. }\end{array}$ & $\begin{array}{l}\text { A importância está } \\
\text { ligada a uma } \\
\text { interdependência, na } \\
\text { qual um precisa do } \\
\text { outro. }\end{array}$ & $\begin{array}{l}\text { Sustento; } \\
\text { Interdependên } \\
\text { cia }\end{array}$ \\
\hline $\begin{array}{l}\text { Pesquisado } \\
10\end{array}$ & Excelente, pois a cada dia aprendo mais. & $\begin{array}{l}\text { Grande, devido o } \\
\text { aprendizado } \\
\text { constante. }\end{array}$ & Excelente \\
\hline
\end{tabular}

Fonte: Dados da pesquisa (2016).

De acordo com o quadro número 1, após o relato dos funcionários, observa-se que todos consideram de grande importância o seu trabalho, onde destacaram que é através do trabalho que irão obter o aprendizado necessário para crescer dentro da empresa e um dos entrevistados destacou que a importância do seu trabalho está relacionada além do fato que a empresa precisa dele, no fato dele precisar do emprego para o seu sustento.

Observa-se, portanto, que a importância do trabalho está diretamente relacionada com a realização pessoal e profissional. Uma questão que se refere principalmente ao crescimento dentro do âmbito organizacional, diretamente relacionado ao crescimento dentro da mesma.

Quadro 2: Nível de eficiência do treinamento que recebe do seu gerente

\begin{tabular}{|c|l|l|c|}
\hline Colaboradores & \multicolumn{1}{|c|}{ Resposta } & \multicolumn{1}{|c|}{ Recorte } & Categoria \\
\hline $\begin{array}{c}\text { Pesquisado } \\
\text { 01 }\end{array}$ & $\begin{array}{l}\text { O gerenciamento da nossa loja é muito } \\
\text { elevado, pois, está sempre procurando } \\
\text { treinar conhecimentos e habilidades de } \\
\text { seus colaboradores. }\end{array}$ & $\begin{array}{l}\text { Elevado nível de } \\
\text { treinamento, procurando } \\
\text { desenvolver } \\
\text { conhecimentos } \\
\text { habilidades. }\end{array}$ & $\begin{array}{c}\text { Conhecimen } \\
\text { to e } \\
\text { habilidade }\end{array}$ \\
\hline $\begin{array}{c}\text { Pesquisado } \\
\mathbf{0 2}\end{array}$ & $\begin{array}{l}\text { Bastante avançado, sempre nos } \\
\text { mantendo informados de assuntos da } \\
\text { empresa, relacionando motivação, } \\
\text { pessoas e resultados. }\end{array}$ & $\begin{array}{l}\text { Avançado treinamento, } \\
\text { buscando sempre trazer } \\
\text { informações no que diz } \\
\text { respeito a empresa }\end{array}$ & $\begin{array}{c}\text { Motivação, pessoas e } \\
\text { resultados }\end{array}$ \\
\hline $\begin{array}{l}\text { Pesquisado } \\
\mathbf{0 3}\end{array}$ & $\begin{array}{l}\text { Elevado nível de treinamento para que eu } \\
\text { possa ser desenvolvida e atingir metas ao } \\
\text { máximo. }\end{array}$ & $\begin{array}{l}\text { Elevado nível de } \\
\text { treinamento, o que } \\
\text { corresponde a um eficiente } \\
\text { numero de metas. }\end{array}$ & $\begin{array}{c}\text { Atingir } \\
\text { metas }\end{array}$ \\
\hline
\end{tabular}




\begin{tabular}{|c|c|c|c|}
\hline $\begin{array}{c}\text { Pesquisado } \\
04\end{array}$ & $\begin{array}{l}\text { Nível altíssimo, pois, é passado o } \\
\text { treinamento e temos total liberdade para } \\
\text { tirar dúvidas. A gerente se preocupa em } \\
\text { saber se estamos colocando em prática os } \\
\text { treinamentos dados. }\end{array}$ & \begin{tabular}{|lr} 
Elevado nível & de \\
treinamento, & \\
desenvolvimento & $\mathrm{e}$ \\
potencialização & das \\
habilidades. &
\end{tabular} & $\begin{array}{l}\text { Elevado } \\
\text { treinamento }\end{array}$ \\
\hline $\begin{array}{l}\text { Pesquisado } \\
05\end{array}$ & $\begin{array}{l}\text { Excelente. Recebo treinamentos online e } \\
\text { presencial. Minha gerente sempre passa } \\
\text { treinamento com eficiência. }\end{array}$ & $\begin{array}{l}\text { Nível excelente de } \\
\text { treinamento, tanto online } \\
\text { quanto presencial. }\end{array}$ & Eficiência \\
\hline $\begin{array}{c}\text { Pesquisado } \\
06\end{array}$ & $\begin{array}{l}\text { Alto. Pois colocamos em prática tudo que } \\
\text { é ensinado através das técnicas e perdura } \\
\text { por muito tempo. }\end{array}$ & $\begin{array}{lr}\text { Alto grau de eficiência } \\
\text { que resultou } \\
\text { maximização } & \text { na } \\
\text { resultados. } & \end{array}$ & $\begin{array}{l}\text { Prática, } \\
\text { técnica }\end{array}$ \\
\hline $\begin{array}{l}\text { Pesquisado } \\
07\end{array}$ & $\begin{array}{l}\text { Bom e altamente produtivo no que diz } \\
\text { respeito aos resultados e motivação da } \\
\text { equipe. }\end{array}$ & $\begin{array}{l}\text { Nível alto de eficiência } \\
\text { relacionado ao rendimento } \\
\text { da empresa e motivação da } \\
\text { equipe. }\end{array}$ & $\begin{array}{c}\text { Resultados; } \\
\text { Motivação }\end{array}$ \\
\hline $\begin{array}{l}\text { Pesquisado } \\
08\end{array}$ & $\begin{array}{l}\text { Gestão muito bem eficiente nos } \\
\text { treinamentos, deixando os colaboradores } \\
\text { bem informados e por dentro das } \\
\text { orientações e campanhas da empresa. }\end{array}$ & $\begin{array}{l}\text { Grande nível de eficiência } \\
\text { e competência nos } \\
\text { treinamentos aplicados } \\
\text { pela gerência. }\end{array}$ & $\begin{array}{c}\text { Informação; } \\
\text { Eficiência }\end{array}$ \\
\hline $\begin{array}{c}\text { Pesquisado } \\
09\end{array}$ & $\begin{array}{l}\text { Excelente. Estamos em constantes } \\
\text { treinamentos para garantir qualidade no } \\
\text { atendimento, metas e satisfação. }\end{array}$ & $\begin{array}{l}\text { Treinamentos constantes } \\
\text { relacionados a traçar metas } \\
\text { para atingir os objetivos e } \\
\text { satisfação. }\end{array}$ & $\begin{array}{c}\text { Metas; } \\
\text { Satisfação }\end{array}$ \\
\hline $\begin{array}{c}\text { Pesquisado } \\
10\end{array}$ & $\begin{array}{l}\text { Ótimo, pois está sempre disposta a nos } \\
\text { ajudar e é bem eficiente no que passa. }\end{array}$ & 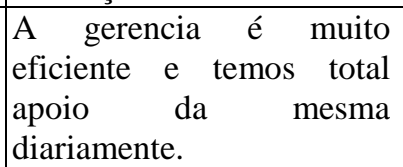 & Eficiente \\
\hline
\end{tabular}

Fonte: Dados da pesquisa (2016).

Em seguida, foram questionados sobre o nível de eficiência do treinamento que recebem do seu gerente, onde os 10 entrevistados classificaram como de alto a excelente nível. Onde são trabalhadas questões pertinentes a motivação dos mesmos, metas a serem atingidas, e são orientados sobre as políticas da empresa, principalmente campanhas. Vale salientar que um dos funcionários destacou que além dos treinamentos presenciais também existem treinamentos online.

Nota-se, no entanto, que o treinamento é fato de extrema importância nas organizações, pois influencia fatores importantes no que diz respeito principalmente a metas, satisfação do cliente, desenvolvimento de habilidades, competências e etc.

A partir dessa questão, foram perguntados para os entrevistados sobre as possibilidades de crescimento dentro da empresa, os quais destacaram no quadro seguinte: 
Quadro 3: Nível de possibilidade de crescimento profissional a empresa lhe proporcionou

\begin{tabular}{|c|c|c|c|}
\hline Colaboradores & Resposta & Recorte & Categoria \\
\hline $\begin{array}{l}\text { Pesquisado } \\
01\end{array}$ & $\begin{array}{l}\text { A empresa me proporciona um grande nível } \\
\text { de crescimento, cabe a mim procurar inovar } \\
\text { meus conhecimentos e assim conseguir } \\
\text { outros conhecimentos profissionais e } \\
\text { crescer dentro da empresa. }\end{array}$ & $\begin{array}{lr}\text { Grande nível } & \text { de } \\
\text { crescimento } & \\
\text { profissional } & \text { para } \\
\text { evoluir dentro } & \text { da } \\
\text { empresa. } & \end{array}$ & $\begin{array}{l}\text { Crescimento } \\
\text { profissional }\end{array}$ \\
\hline $\begin{array}{l}\text { Pesquisado } \\
02\end{array}$ & $\begin{array}{l}\text { Acredito que a empresa vem utilizando } \\
\text { varias ferramentas que nos capacita a um } \\
\text { grande crescimento, nos estimulando e } \\
\text { preparando cada vez mais através de } \\
\text { treinamentos e dinâmicas. }\end{array}$ & $\begin{array}{lr}\text { Capacitação } & \\
\text { profissional } & \text { através } \\
\text { treinamentos } & \mathrm{e} \\
\text { dinâmicas. } & \end{array}$ & Ferramentas \\
\hline $\begin{array}{l}\text { Pesquisado } \\
03\end{array}$ & $\begin{array}{l}\text { A empresa proporciona total nível de } \\
\text { crescimento, cabe a cada colaborador se } \\
\text { dedicar e tentar ir ao longe com suas } \\
\text { capacidades. }\end{array}$ & $\begin{array}{l}\text { O nível de crescimento } \\
\text { profissional depende do } \\
\text { comprometimento e da } \\
\begin{array}{l}\text { capacidade dos } \\
\text { colaboradores. }\end{array}\end{array}$ & Capacidade \\
\hline $\begin{array}{c}\text { Pesquisado } \\
04\end{array}$ & $\begin{array}{l}\text { Sou nova na empresa, mas já me vejo em } \\
\text { um cargo acima, vejo uma grande } \\
\text { possibilidade de crescimento e sei que } \\
\text { dependo dos meus esforços para conseguir. }\end{array}$ & $\begin{array}{l}\text { Isso depende do meus } \\
\text { esforço, dedicação e } \\
\text { comprometimento. }\end{array}$ & Esforço \\
\hline $\begin{array}{l}\text { Pesquisado } \\
05\end{array}$ & $\begin{array}{l}\text { No momento estou trabalhando para } \\
\text { concorrer a cargos mais elevados, porém } \\
\text { sou novato. }\end{array}$ & $\begin{array}{l}\text { A possibilidade de } \\
\text { crescimento dentro da } \\
\text { empresa depende do } \\
\text { meu nível de eficiência. }\end{array}$ & $\begin{array}{l}\text { Cargos mais } \\
\text { elevados }\end{array}$ \\
\hline $\begin{array}{l}\text { Pesquisado } \\
06\end{array}$ & $\begin{array}{l}\text { Muitas. Muitas chances de crescer dentro } \\
\text { da empresa em várias áreas. }\end{array}$ & $\begin{array}{lr}\text { Grande nível } & \text { de } \\
\text { crescimento } & \mathrm{em} \\
\text { diversas áreas. } & \\
\end{array}$ & $\begin{array}{l}\text { Crescimento } \\
\text { interno }\end{array}$ \\
\hline $\begin{array}{l}\text { Pesquisado } \\
07\end{array}$ & $\begin{array}{l}\text { Grande nível de crescimento profissional } \\
\text { para evoluir dentro da empresa. }\end{array}$ & $\begin{array}{l}\text { Um nível muito } \\
\text { elevado, tanto pessoal } \\
\text { quanto profissional. }\end{array}$ & Evolução \\
\hline $\begin{array}{l}\text { Pesquisado } \\
08\end{array}$ & $\begin{array}{l}\text { A empresa proporciona muita oportunidade } \\
\text { de crescimento, vai de cada colaborador. O } \\
\text { meu caso, ainda estou em desenvolvimento. } \\
\text { É questão de tempo. }\end{array}$ & $\begin{array}{l}\text { O nível de crescimento } \\
\text { está diretamente } \\
\text { relacionado ao grau de } \\
\text { desempenho de cada } \\
\text { um que trabalha na } \\
\text { empresa }\end{array}$ & $\begin{array}{l}\text { Crescimento; } \\
\text { Desenvolvim } \\
\quad \text { ento }\end{array}$ \\
\hline $\begin{array}{c}\text { Pesquisado } \\
09\end{array}$ & $\begin{array}{l}\text { Grande. Mas vale lembrar que tudo } \\
\text { depende de si mesmo. }\end{array}$ & $\begin{array}{l}\text { O nível de crescimento } \\
\text { depende de cada um. }\end{array}$ & $\begin{array}{l}\text { Possibilidade } \\
\text { Individual }\end{array}$ \\
\hline $\begin{array}{c}\text { Pesquisado } \\
10\end{array}$ & $\begin{array}{l}\text { Está sempre } \text { nos preparando, com } \\
\text { treinamentos e surgindo sempre novas } \\
\text { vagas. }\end{array}$ & $\begin{array}{l}\text { Constantes } \\
\text { possibilidades. }\end{array}$ & Preparação \\
\hline
\end{tabular}

Fonte: Dados da pesquisa (2016).

Onde pode-se observar que a empresa oferece total crescimento profissional aos colaboradores, no entanto, esse fato está diretamente ligado ao empenho e comprometimento de cada um.

Assim, observa-se que tanto a empresa estudada, como várias outras, estão preocupadas com o aperfeiçoamento dos colaboradores, e sabe que isso irá refletir em um melhor rendimento da empresa. 
Nesse sentido, gerou-se uma inquietação para se saber se eles passaram por algum tipo de dificuldade de equilíbrio entre a vida pessoal e profissional durante sua contribuição na empresa, onde o quadro 4 nos mostra com nitidez que quase nenhum deles encontraram dificuldades, e apenas um destacou que sua única dificuldade foi questão horário por nunca ter trabalhado no período noturno, no entanto já está adaptado. Como segue no quadro 4.

Quadro 4: Grau de dificuldade enfrentado para equilibrar vida profissional e pessoal enquanto trabalha.

\begin{tabular}{|c|c|c|c|}
\hline Colaboradores & Resposta & Recorte & Categoria \\
\hline $\begin{array}{c}\text { Pesquisado } \\
01\end{array}$ & $\begin{array}{l}\text { Não exatamente por conta da empresa, } \\
\text { mas por conta do horário de shopping } \\
\text { que é extenso. Essa foi a maior } \\
\text { dificuldade; trabalhar na empresa, não } \\
\text { encontrei dificuldade. }\end{array}$ & $\begin{array}{l}\text { A maior dificuldade foi a } \\
\text { questão de adaptação ao } \\
\text { horário de shopping. }\end{array}$ & Horário \\
\hline $\begin{array}{c}\text { Pesquisado } \\
02\end{array}$ & $\begin{array}{l}\text { Não tenho do que questionar, tenho } \\
\text { total equilíbrio entre o pessoal e o } \\
\text { profissional. }\end{array}$ & $\begin{array}{l}\text { Total equilíbrio, tanto } \\
\text { pessoal quanto } \\
\text { profissional. }\end{array}$ & Equilíbrio \\
\hline $\begin{array}{c}\text { Pesquisado } \\
03\end{array}$ & Não encontrei dificuldades & $\begin{array}{l}\text { Não houve nenhum } \\
\text { nível de dificuldade. }\end{array}$ & $\begin{array}{l}\text { Não } \\
\text { informado }\end{array}$ \\
\hline $\begin{array}{c}\text { Pesquisado } \\
04\end{array}$ & $\begin{array}{l}\text { A maior dificuldade foi o horário, } \\
\text { porque eu nunca havia trabalhado a } \\
\text { noite, porém já me adaptei e estou } \\
\text { amando por sinal. }\end{array}$ & $\begin{array}{l}\text { A maior dificuldade foi } \\
\text { a questão de adaptação } \\
\text { ao horário de shopping. }\end{array}$ & Horário \\
\hline $\begin{array}{c}\text { Pesquisado } \\
05\end{array}$ & Nenhuma dificuldade até o momento. & $\begin{array}{l}\text { Não foram identificadas } \\
\text { nenhuma dificuldade. }\end{array}$ & $\begin{array}{l}\text { Não } \\
\text { informado }\end{array}$ \\
\hline $\begin{array}{c}\text { Pesquisado } \\
06 \\
\end{array}$ & Não tive dificuldades. & Não houve dificuldades. & $\begin{array}{l}\text { Não } \\
\text { informado }\end{array}$ \\
\hline $\begin{array}{c}\text { Pesquisado } \\
07\end{array}$ & $\begin{array}{l}\text { Não. Venho trabalhando para } \\
\text { equilibrar minha vida pessoal, sem que } \\
\text { reflita na minha vida profissional. }\end{array}$ & $\begin{array}{lll}\text { Saber distinguir } & \text { o lado } \\
\text { pessoal do } & \text { lado } \\
\text { profissional } & \\
\end{array}$ & Equilíbrio \\
\hline $\begin{array}{c}\text { Pesquisado } \\
08\end{array}$ & $\begin{array}{l}\text { Nenhuma. Não tive dificuldade para } \\
\text { equilibrar minha vida, foi mais questão } \\
\text { de adaptação mesmo, dos costumes e } \\
\text { da ideologia da empresa. }\end{array}$ & $\begin{array}{l}\text { Não houve dificuldade } \\
\text { no que diz respeito ao } \\
\text { equilíbrio entre o pessoal } \\
\text { e o profissional. }\end{array}$ & Adaptação \\
\hline $\begin{array}{c}\text { Pesquisado } \\
09\end{array}$ & Nunca tive dificuldade. & Não houve dificuldades & $\begin{array}{l}\text { Não } \\
\text { informado }\end{array}$ \\
\hline $\begin{array}{c}\text { Pesquisado } \\
10\end{array}$ & $\begin{array}{l}\text { Até o momento não encontrei } \\
\text { dificuldade, pois tenho equilíbrio } \\
\text { emocional em separar profissional com } \\
\text { pessoal. }\end{array}$ & Nenhuma dificuldade & $\begin{array}{l}\text { Equilíbrio } \\
\text { emocional }\end{array}$ \\
\hline
\end{tabular}

Fonte: Dados da pesquisa (2016).

Tendo em vista que os colaboradores destacaram que estão em constantes treinamentos, questionou-se o significado do Coaching, como nos mostra o quadro 5: 
Quadro 5: Sabe o que é Coaching?

\begin{tabular}{|c|c|c|c|}
\hline Colaboradores & Resposta & Recorte & Categoria \\
\hline $\begin{array}{l}\text { Pesquisado } \\
01\end{array}$ & $\begin{array}{l}\text { Sim. Ferramenta de desenvolvimento } \\
\text { pessoal e profissional. (treinar ou ensinar) }\end{array}$ & $\begin{array}{l}\text { Ferramenta de } \\
\text { desenvolvimento } \\
\text { pessoal e profissional }\end{array}$ & $\begin{array}{l}\text { Treinar ou } \\
\text { ensinar }\end{array}$ \\
\hline $\begin{array}{l}\text { Pesquisado } \\
02\end{array}$ & $\begin{array}{l}\text { É uma oportunidade de visualização clara } \\
\text { dos pontos individuais, de aumento da } \\
\text { auto-confiança, de quebrar barreiras de } \\
\text { limitação, assim atingindo seu potencial } \\
\text { máximo e alcançar suas metas de forma } \\
\text { objetiva e principalmente assertiva. }\end{array}$ & $\begin{array}{l}\text { Melhor visualização } \\
\text { dos pontos } \\
\text { individuais, quebra } \\
\text { de barreiras de } \\
\text { limitação e uma } \\
\text { melhor forma de } \\
\text { atingir os objetivos. }\end{array}$ & $\begin{array}{l}\text { Quebra de } \\
\text { barreiras }\end{array}$ \\
\hline $\begin{array}{l}\text { Pesquisado } \\
03\end{array}$ & $\begin{array}{l}\text { Sim. Uma forma de evoluir, o Coaching } \\
\text { ensina alguém a crescer evoluir em } \\
\text { alguma área de sua vida. }\end{array}$ & 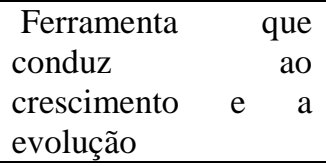 & $\begin{array}{l}\text { Crescimento } \\
\text { e evolução }\end{array}$ \\
\hline $\begin{array}{l}\text { Pesquisado } \\
04\end{array}$ & $\begin{array}{l}\text { Sim. Quem prepara para algo. Um } \\
\text { instrutor. }\end{array}$ & $\begin{array}{l}\text { Pessoa que auxilia a } \\
\text { atingir determinado } \\
\text { objetivo }\end{array}$ & Instrutor \\
\hline $\begin{array}{l}\text { Pesquisado } \\
\text { 05 }\end{array}$ & $\begin{array}{l}\text { Sim. Pessoa que realiza treinamento, } \\
\text { espécie de instrutor. }\end{array}$ & $\begin{array}{l}\text { Espécie de } \\
\text { treinador, instrutor. }\end{array}$ & Treinamento \\
\hline $\begin{array}{l}\text { Pesquisado } \\
06\end{array}$ & $\begin{array}{l}\text { Sim. Uma pessoa que auxilia outras } \\
\text { pessoas a atingir determinado resultado. }\end{array}$ & $\begin{array}{l}\mathrm{Um} \text { treinador que } \\
\text { desenvolve pessoas. }\end{array}$ & Resultados \\
\hline $\begin{array}{l}\text { Pesquisado } \\
07\end{array}$ & $\begin{array}{l}\text { Sim. } \quad \text { É um } \quad \text { treinamento de } \\
\text { desenvolvimento pessoal e profissional. }\end{array}$ & $\begin{array}{lr}\text { Treinamento } & \mathrm{de} \\
\text { pessoas } & \mathrm{e} \\
\text { profissionais } & \\
\end{array}$ & Treinamento \\
\hline $\begin{array}{l}\text { Pesquisado } \\
08\end{array}$ & $\begin{array}{l}\text { Sim. É tipo um instrutor ou treinador que } \\
\text { ajuda as pessoas. }\end{array}$ & $\begin{array}{l}\text { Espécie de instrutor } \\
\text { que conduz as } \\
\text { pessoas. }\end{array}$ & Instrutor \\
\hline $\begin{array}{c}\text { Pesquisado } \\
09\end{array}$ & Sim. & Não informado & $\begin{array}{l}\text { Não } \\
\text { informado }\end{array}$ \\
\hline $\begin{array}{l}\text { Pesquisado } \\
10\end{array}$ & $\begin{array}{l}\text { Sim. É o líder que ensina ao seu } \\
\text { colaborador. }\end{array}$ & Ato de liderar & Líder \\
\hline
\end{tabular}

Fonte: Dados da pesquisa (2016).

De acordo com o quadro número 05, após todo o relato dos funcionários, observa-se que todos eles sabem o conceito do Coaching na sua essência e destacaram que está implicitamente relacionado a capacidade de treinar ou liderar uma equipe. Apenas um, dos entrevistados não definiu o conceito, só relatou que sabia do que se tratava.

Verifica-se que o Coaching tem conquistado cada vez mais o seu espaço nas organizações e na vida das pessoas. Foi possível observar isso quando todos funcionários afirmaram saber o que isso significava, e na essência, todos se colocaram muito bem e ressaltaram o quanto puderam melhorar tanto no pessoal, quanto no profissional.

Em seguida, no quadro 6, perguntou-se sobre a percepção que eles tinham sobre as técnicas utilizadas na empresa. 
Quadro 6: Percepção de técnicas de Coaching sendo utilizadas na empresa

\begin{tabular}{|c|c|c|c|}
\hline Colaboradores & Resposta & Recorte & Categoria \\
\hline $\begin{array}{l}\text { Pesquisado } \\
01\end{array}$ & $\begin{array}{l}\text { Trabalha sempre o conhecimento de seus } \\
\text { colaboradores, treinando-os diariamente } \\
\text { para as dificuldades diárias. }\end{array}$ & $\begin{array}{lr}\text { Constante treino } & \text { dos } \\
\text { colaboradores } & \text { para } \\
\text { aperfeiçoar } & \text { os } \\
\text { conhecimentos } & \text { e } \\
\text { enfrentar dificuldades }\end{array}$ & Treino \\
\hline $\begin{array}{l}\text { Pesquisado } \\
02\end{array}$ & $\begin{array}{l}\text { Bastante avançada, nos motivando, } \\
\text { desenvolvendo e nos preparando, nos } \\
\text { fazendo sentir capacitados. }\end{array}$ & $\begin{array}{lr}\text { Uso de técnicas } \\
\text { avançadas, } \\
\text { trabalhando } & \text { a } \\
\text { motivação } & \text { e } \\
\text { melhoramento } & \text { das } \\
\text { capacidades } & \\
\end{array}$ & Motivação \\
\hline $\begin{array}{l}\text { Pesquisado } \\
03\end{array}$ & $\begin{array}{l}\text { A empresa trabalha junto com todos os } \\
\text { funcionários se adequando a novos } \\
\text { padrões como as pesquisas de clima, } \\
\text { gerenciamento do tempo, aumento de } \\
\text { autoconfiança, maximização dos } \\
\text { resultados. }\end{array}$ & $\begin{array}{l}\text { Técnicas que auxiliam } \\
\text { na adaptação de } \\
\text { processos e melhoria } \\
\text { da capacidade. }\end{array}$ & $\begin{array}{l}\text { Maximização } \\
\text { dos resultados }\end{array}$ \\
\hline $\begin{array}{l}\text { Pesquisado } \\
04\end{array}$ & $\begin{array}{l}\text { Ótimas técnicas. No meu caso pude } \\
\text { passar uma semana sendo orientado por } \\
\text { um "padrinho" para me familiarizar, e } \\
\text { mais os treinamentos dados que } \\
\text { facilitaram muito o meu trabalho. }\end{array}$ & $\begin{array}{lr}\text { Ótimas técnicas } & \text { e } \\
\text { estratégias } & \text { de } \\
\text { desenvolvimento. } & \end{array}$ & Treinamento \\
\hline $\begin{array}{l}\text { Pesquisado } \\
05\end{array}$ & $\begin{array}{l}\text { As minhas chefas sempre me instruem a } \\
\text { fazer o melhor para potencialização dos } \\
\text { resultados da empresa. }\end{array}$ & $\begin{array}{l}\text { Acompanhamento da } \\
\text { gerência nas atividades } \\
\text { organizacionais. }\end{array}$ & $\begin{array}{l}\text { Potencializaç } \\
\text { ão }\end{array}$ \\
\hline $\begin{array}{l}\text { Pesquisado } \\
06\end{array}$ & $\begin{array}{l}\text { Excelente. Pois aprendi muito e cresci } \\
\text { com os feedbacks que recebi. }\end{array}$ & $\begin{array}{l}\text { Várias técnicas. Os } \\
\text { resultados } \\
\text { medidos ano } \\
\text { feedbacks gerencias. }\end{array}$ & Feedback \\
\hline $\begin{array}{l}\text { Pesquisado } \\
07\end{array}$ & $\begin{array}{l}\text { Capacitação de profissionais, metas, } \\
\text { trabalho em equipe, atingir resultados } \\
\text { mais rapidamente. }\end{array}$ & $\begin{array}{l}\text { Ferramentas para } \\
\text { atingir resultados de } \\
\text { forma eficiente }\end{array}$ & Metas \\
\hline $\begin{array}{l}\text { Pesquisado } \\
08\end{array}$ & $\begin{array}{l}\text { A liderança, desenvolver bem os } \\
\text { colaboradores, ajudando a evoluir } \\
\text { profissionalmente. }\end{array}$ & $\begin{array}{l}\text { Desenvolvimento de } \\
\text { liderança e de pessoas, } \\
\text { que contribui para a } \\
\text { sua evolução e } \\
\text { desempenho. }\end{array}$ & Liderança \\
\hline $\begin{array}{l}\text { Pesquisado } \\
09\end{array}$ & $\begin{array}{l}\text { Boa percepção. A empresa sempre } \\
\text { está pronta para nos ajudar, como } \\
\text { planos de cargos e carreiras e etc. }\end{array}$ & $\begin{array}{l}\text { Adoção de técnicas e } \\
\text { ferramentas diárias. }\end{array}$ & Planejamento \\
\hline $\begin{array}{c}\text { Pesquisado } \\
10 \\
\end{array}$ & $\begin{array}{l}\text { A liderança, saber desenvolver bem os } \\
\text { seus colaboradores. }\end{array}$ & Boa liderança & Liderança \\
\hline
\end{tabular}

Fonte: Dados da pesquisa (2016).

De acordo com o quadro 06 que questiona sobre a percepção que os colaboradores tem a cerca das técnicas de Coaching utilizadas na empresa, onde destacaram uso de técnicas bastante avançadas e eficientes no que diz respeito a fatores como liderança, capacitação dos profissionais, feedback e et. 
Observa-se, contudo, que a utilização dessas técnicas tem proporcionado um melhor papel da liderança, refletindo sempre em uma melhor motivação dos funcionários, melhor planejamento e potencialização dos resultados.

A partir disso, foi perguntado para os entrevistados sobre as contribuições que essas técnicas lhes proporcionaram e responderam conforme mostram os seguintes dados:

Quadro 7: Essas técnicas proporcionaram contribuições para o seu desenvolvimento pessoal?

\begin{tabular}{|c|c|c|c|}
\hline Colaboradores & Resposta & Recorte & Categoria \\
\hline $\begin{array}{c}\text { Pesquisado } \\
\text { 01 }\end{array}$ & $\begin{array}{l}\text { Sim. Pois nos torna mais ágeis a } \\
\text { acontecimentos } \\
\begin{array}{l}\text { cotidianos. } \\
\text { proporciona também o equilíbrio pessoal. }\end{array}\end{array}$ & $\begin{array}{lr}\text { Agilidade } & \text { para lidar } \\
\text { com } & \text { problemas } \\
\text { cotidianos } & \\
\end{array}$ & $\begin{array}{l}\text { Equilíbrio } \\
\text { pessoal }\end{array}$ \\
\hline $\begin{array}{l}\text { Pesquisado } \\
02\end{array}$ & $\begin{array}{l}\text { Sim. Influenciando em decisões, nos } \\
\text { despertando interesses e cada vez mais, e } \\
\text { vontade de mostrar o melhor. }\end{array}$ & $\begin{array}{l}\text { Melhoramento da } \\
\text { capacidade de tomar } \\
\text { decisões }\end{array}$ & Decisões \\
\hline $\begin{array}{l}\text { Pesquisado } \\
03\end{array}$ & $\begin{array}{l}\text { Sim. Maior equilíbrio e no trabalho } \\
\text { aprendemos a lidar com vários tipos de } \\
\text { pessoas, em algumas situações que } \\
\text { levamos como aprendizado para a vida } \\
\text { pessoal. }\end{array}$ & $\begin{array}{l}\text { Potencialização das } \\
\text { habilidades } \\
\text { interpessoais. }\end{array}$ & $\begin{array}{l}\text { Equilíbrio } \\
\text { pessoal }\end{array}$ \\
\hline $\begin{array}{c}\text { Pesquisado } \\
04\end{array}$ & $\begin{array}{l}\text { Sim. Aprendizados essenciais pra mim, } \\
\text { tanto na empresa, quanto para } \\
\text { desenvolvimento pessoal, por saber lidar } \\
\text { com pessoas em diversas situações. }\end{array}$ & $\begin{array}{l}\text { Aprendizado } \\
\text { profissional e } \\
\text { principalmente pessoal } \\
\text { no que diz respeito a } \\
\text { gerenciar conflitos. }\end{array}$ & $\begin{array}{l}\text { Equilíbrio } \\
\text { pessoal }\end{array}$ \\
\hline $\begin{array}{l}\text { Pesquisado } \\
05\end{array}$ & $\begin{array}{l}\text { Sim, bastante. Aprendi a lidar melhor com } \\
\text { problemas e conflitos. }\end{array}$ & $\begin{array}{l}\text { Melhor } \\
\text { aperfeiçoamento da } \\
\text { capacidade de relações. }\end{array}$ & Conflitos \\
\hline $\begin{array}{l}\text { Pesquisado } \\
06\end{array}$ & $\begin{array}{l}\text { Muitas. Só veio a somar no meu } \\
\text { desenvolvimento para o crescimento } \\
\text { como pessoa e acrescentar uma nova } \\
\text { missão. }\end{array}$ & $\begin{array}{l}\text { Crescimento contínuo } \\
\text { refletido em um melhor } \\
\text { rendimento. }\end{array}$ & $\begin{array}{l}\text { Desenvolvime } \\
\text { nto, } \\
\text { Crescimento }\end{array}$ \\
\hline $\begin{array}{c}\text { Pesquisado } \\
07 \\
\end{array}$ & $\begin{array}{l}\text { Sim. Aprendi a lidar e me adaptar melhor } \\
\text { com pessoas e problemas. }\end{array}$ & $\begin{array}{ll}\text { Melhores relações } \\
\text { interpessoais }\end{array}$ & Adaptação \\
\hline $\begin{array}{l}\text { Pesquisado } \\
08\end{array}$ & $\begin{array}{l}\text { Com certeza. Hoje sou uma pessoa mais } \\
\text { apta no desenvolvimento das minhas } \\
\text { competências. }\end{array}$ & $\begin{array}{l}\text { Melhoria da capacidade } \\
\text { de desempenho } \\
\text { pessoal. }\end{array}$ & Competências \\
\hline $\begin{array}{l}\text { Pesquisado } \\
09\end{array}$ & $\begin{array}{l}\text { Sim. Principalmente no que diz respeito a } \\
\text { saber lidar com pessoas e quebrar } \\
\text { barreiras. }\end{array}$ & $\begin{array}{l}\text { Melhoria da capacidade } \\
\text { de trabalhar com } \\
\text { pessoas. }\end{array}$ & $\begin{array}{l}\text { Quebra de } \\
\text { barreiras }\end{array}$ \\
\hline $\begin{array}{c}\text { Pesquisado } \\
10 \\
\end{array}$ & Sim, e muito. & Muito & Muito \\
\hline
\end{tabular}

Fonte: Dados da pesquisa (2016).

Todos destacaram que foram inúmeras as contribuições, principalmente no sentido de melhorias as relações interpessoais, aumento da autoconfiança, quebra de barreiras, etc. 
No entanto, observa-se que a utilização dessas técnicas contribui para o desenvolvimento pessoal e profissional, porém, foi percebido que a empresa se preocupa quase que somente com a questão profissional, o que seria necessário também desenvolver técnicas que auxiliem os funcionários a melhorar cada vez mais também o seu lado pessoal.

Por conseguinte, foram abordados sobre os resultados da empresa.

Quadro 8: Os resultados foram mais rápidos, eficientes e duradouros?

\begin{tabular}{|c|c|c|c|}
\hline Colaboradores & Resposta & Recorte & Categoria \\
\hline $\begin{array}{l}\text { Pesquisado } \\
01\end{array}$ & $\begin{array}{l}\text { Com certeza, tudo depende do quanto } \\
\text { você absorve, mas ao meu ponto de vista } \\
\text { os resultados foram muito eficientes e } \\
\text { duradouros. }\end{array}$ & $\begin{array}{l}\text { Tudo depende do } \\
\text { conhecimento absorvido }\end{array}$ & $\begin{array}{l}\text { Eficientes e } \\
\text { duradouros }\end{array}$ \\
\hline $\begin{array}{l}\text { Pesquisado } \\
02\end{array}$ & $\begin{array}{l}\text { Sim. A empresa se preocupa com o } \\
\text { desempenho dos seus colaboradores, } \\
\text { dessa forma é usado planos de ação, a } \\
\text { onde nos direciona a exercer melhor o } \\
\text { nosso trabalho. }\end{array}$ & $\begin{array}{l}\text { Devido a preocupação da } \\
\text { empresa com o } \\
\text { desempenho } \\
\text { colaboradores, dos } \\
\text { desenvolvidos planos de } \\
\text { ação com certa } \\
\text { frequiência para um } \\
\text { melhor direcionamento } \\
\text { no trabalho. }\end{array}$ & $\begin{array}{l}\text { Planos de } \\
\text { ação }\end{array}$ \\
\hline $\begin{array}{l}\text { Pesquisado } \\
03\end{array}$ & $\begin{array}{l}\text { Sim. Os resultados foram significativos, } \\
\text { temos pessoas mais focadas, } \\
\text { determinadas a conseguirem seus } \\
\text { objetivos e evoluir com a empresa. }\end{array}$ & $\begin{array}{lr}\text { Resultados } & \text { mais } \\
\text { eficientes refletido em } \\
\text { pessoas } \\
\text { comprometidas. }\end{array}$ & $\begin{array}{l}\text { Foco; } \\
\text { Comprometi } \\
\text { mento }\end{array}$ \\
\hline $\begin{array}{l}\text { Pesquisado } \\
04\end{array}$ & $\begin{array}{l}\text { Sim. Estamos em constante treinamento } \\
\text { na empresa para aprender e colocar tudo } \\
\text { em prática. Com isso, os resultados } \\
\text { fluem. }\end{array}$ & $\begin{array}{l}\text { Os resultados são } \\
\text { reflexos } \\
\text { treinamentos recebidos, } \\
\text { que sempre resultam em } \\
\text { resultados cada vez } \\
\text { melhores. }\end{array}$ & $\begin{array}{l}\text { Melhores } \\
\text { resultados }\end{array}$ \\
\hline $\begin{array}{l}\text { Pesquisado } \\
05\end{array}$ & $\begin{array}{l}\text { Sim. Através das técnicas aplicadas, } \\
\text { resultaram em resultados cada vez mais } \\
\text { satisfatórios. }\end{array}$ & \begin{tabular}{lll}
\multicolumn{2}{l}{ Potencialização } & das \\
habilidades cada & vez \\
maiores. & & \\
\end{tabular} & $\begin{array}{l}\text { Resultados } \\
\text { satisfatórios }\end{array}$ \\
\hline $\begin{array}{c}\text { Pesquisado } \\
06\end{array}$ & $\begin{array}{l}\text { Sim. Cada vez mais os resultados são } \\
\text { comprovados. }\end{array}$ & Sempre mais. & $\begin{array}{l}\text { Resultados } \\
\text { Eficientes }\end{array}$ \\
\hline $\begin{array}{l}\text { Pesquisado } \\
07\end{array}$ & $\begin{array}{l}\text { Sim. Sem dúvidas, os resultados foram } \\
\text { bem nítidos e houve muitas melhorias } \\
\text { nos processos contínuos da empresa e } \\
\text { trabalho em equipe. }\end{array}$ & $\begin{array}{l}\text { Melhoria significativas } \\
\text { dos processos e pessoas. }\end{array}$ & Processos \\
\hline $\begin{array}{c}\text { Pesquisado } \\
08\end{array}$ & $\begin{array}{l}\text { Sim. Tanto os resultados como as } \\
\text { relações melhoraram bastante e tem } \\
\text { surtido um efeito bem duradouro. }\end{array}$ & $\begin{array}{l}\text { Tanto nos resultados } \\
\text { como nas relações. }\end{array}$ & $\begin{array}{l}\text { Relações; } \\
\text { Resultados }\end{array}$ \\
\hline $\begin{array}{c}\text { Pesquisado } \\
09\end{array}$ & Duradouros & Não informado & $\begin{array}{c}\text { Não } \\
\text { informado }\end{array}$ \\
\hline $\begin{array}{c}\text { Pesquisado } \\
10 \\
\end{array}$ & Sim. Constantes resultados. & $\begin{array}{l}\text { Constante melhoria de } \\
\text { resultados }\end{array}$ & Constantes \\
\hline
\end{tabular}

Fonte: Dados da pesquisa (2016). 
Onde fica nítido que os resultados foram bem significativos no que diz respeito ao melhor trabalho em equipe, produtividade, melhoria dos processos e dos resultados. Principalmente pelo fato de estarem em constantes treinamentos.

Verifica-se, nesse sentido, que é constante a melhoria dos resultados dentro da organização, principalmente comparando aos balanços anteriores.

Em seguida, no quadro 09 procurou-se saber se houve influencia nas relações pessoais e profissionais

Quadro 9: Houve uma melhoria nas relações pessoais e profissionais?

\begin{tabular}{|c|c|c|c|}
\hline Colaboradores & Resposta & Recorte & Categoria \\
\hline $\begin{array}{c}\text { Pesquisado } \\
\text { 01 }\end{array}$ & $\begin{array}{l}\text { Houve uma imensa melhoria. } \\
\text { Crescimento elevado tanto pessoal } \\
\text { quanto profissional. }\end{array}$ & Imensa melhoria & $\begin{array}{l}\text { Crescimento } \\
\text { pessoal e } \\
\text { profissional }\end{array}$ \\
\hline $\begin{array}{c}\text { Pesquisado } \\
02\end{array}$ & $\begin{array}{l}\text { Sim. As técnicas aplicadas possibilitaram } \\
\text { uma melhor convivência no âmbito de } \\
\text { trabalho, maior motivação e } \\
\text { comprometimento com os resultados da } \\
\text { empresa. }\end{array}$ & $\begin{array}{l}\text { O clima organizacional } \\
\text { melhorou } \\
\text { significativamente, bem } \\
\text { como as relações } \\
\text { interpessoais e melhor } \\
\text { resultado das metas }\end{array}$ & $\begin{array}{l}\text { Comprometi } \\
\text { mento }\end{array}$ \\
\hline $\begin{array}{c}\text { Pesquisado } \\
03\end{array}$ & $\begin{array}{l}\text { Sim. Pessoas mais maduras e felizes e } \\
\text { que conseguem separar o pessoal do } \\
\text { profissional. }\end{array}$ & $\begin{array}{l}\text { Capacidade de melhoria } \\
\text { das relações } \\
\text { interpessoais }\end{array}$ & $\begin{array}{l}\text { Equilíbrio } \\
\text { pessoal e } \\
\text { profissional } \\
\end{array}$ \\
\hline $\begin{array}{l}\text { Pesquisado } \\
\text { 04 }\end{array}$ & $\begin{array}{l}\text { Houve sim, bastante. Cada vez mais } \\
\text { melhorias nas relações e diminuição de } \\
\text { conflitos internos. }\end{array}$ & $\begin{array}{l}\text { Melhores relações } \\
\text { pessoais } \\
\text { consequentemente } \\
\text { menos conflitos. }\end{array}$ & $\begin{array}{l}\text { Crescimento } \\
\text { pessoal e } \\
\text { profissional }\end{array}$ \\
\hline $\begin{array}{c}\text { Pesquisado } \\
05\end{array}$ & $\begin{array}{l}\text { Houve sim, bastante. Cada vez mais } \\
\text { melhorias nas relações e diminuição de } \\
\text { conflitos internos. }\end{array}$ & $\begin{array}{lr}\text { Grande melhoria } & \text { nas } \\
\text { relações } & \mathrm{e} \\
\text { gerenciamento } & \mathrm{de} \\
\text { conflitos. } & \end{array}$ & $\begin{array}{l}\text { Diminuição } \\
\text { de conflitos }\end{array}$ \\
\hline $\begin{array}{c}\text { Pesquisado } \\
06\end{array}$ & $\begin{array}{l}\text { Sim. O meu entrosamento e comunicação } \\
\text { com as pessoas que me cercam, na parte } \\
\text { pessoal e profissional. }\end{array}$ & Constantes melhorias & Comunicação \\
\hline $\begin{array}{l}\text { Pesquisado } \\
\text { 07 }\end{array}$ & $\begin{array}{l}\text { Sim. Estamos muito melhores em nossas } \\
\text { relações. }\end{array}$ & $\begin{array}{l}\text { Grande melhoria das } \\
\text { relações interpessoais. }\end{array}$ & $\begin{array}{l}\text { Melhores } \\
\text { relações }\end{array}$ \\
\hline $\begin{array}{c}\text { Pesquisado } \\
08\end{array}$ & $\begin{array}{l}\text { Sim. E sempre há, através das constantes } \\
\text { oportunidades do dia a dia da empresa. }\end{array}$ & $\begin{array}{l}\text { Melhorias através da } \\
\text { política da empresa }\end{array}$ & Oportunidades \\
\hline $\begin{array}{c}\text { Pesquisado } \\
\text { 09 }\end{array}$ & Sim. Foram inúmeras as melhorias. & Grandes melhorias & Inúmeras \\
\hline $\begin{array}{c}\text { Pesquisado } \\
10\end{array}$ & $\begin{array}{l}\text { Sim. Sinto-me plenamente realizado com } \\
\text { o meu trabalho, com isso me relaciono } \\
\text { mais fácil com os meus colegas de } \\
\text { trabalho. }\end{array}$ & $\begin{array}{l}\text { Realização pessoal e } \\
\text { profissional, resultando } \\
\text { em um bom trabalho e } \\
\text { boa relação com os } \\
\text { colegas. }\end{array}$ & Realizado \\
\hline
\end{tabular}

Fonte: Dados da pesquisa (2016). 
Onde destacou-se de forma geral que houve uma melhoria significativa das relações dentro e fora do ambiente de trabalho.

Nesse sentido, pode-se perceber o quanto a utilização dessas técnicas tem contribuído com os resultados. Fator este que implica na melhoria dos conflitos e do clima organizacional.

\title{
Entrevista com o Gestor
}

Após o questionário aplicado aos colaboradores da respectiva loja, fez-se uma entrevista com a gerência, onde, caracteriza-se, do sexo feminino, 28 anos de idade, trabalha nesta função há 11 anos e já passou por experiência de gestão antes dessa função, onde a mesma coloca que foi supervisora de setor.

No primeiro momento procurou-se saber se a gerente utiliza técnicas de Coaching na sua gestão, a qual ressaltou que:

\begin{abstract}
Sim. Desenvolver os colaboradores sobre minha responsabilidade para o atingimento de seus resultados que podem ser pessoais, como profissionais. Busco desenvolver as melhores competências dos colaboradores, através de treinamentos presenciais e acompanhamento e correção de postura na prática. Ensinar com exatidão como executar determinar tarefa ou atingir um objetivo. Faz planejamento com o seu colaborador e acompanha sua evolução para depois aplicar o feedback. Treinamento on-line. (DADOS DA GERENTE ENTREVISTADA, 2016).
\end{abstract}

A partir disso, questionou-se sobre sua opinião a respeito das contribuições das técnicas Coaching para o desenvolvimento da liderança em organizações comerciais, a qual afirmou ser essencial para gestor, uma vez que é o disseminador da cultura e objetivos dentro da empresa atuante. E que o gerente deve ser acima de tudo, um bom treinador, já que está a frente de pessoas, processos e clientes, que levam as empresas terem sucesso. Nesse sentido, também perguntou-se sobre os aspectos em que o Coaching tem contribuído nos resultados da empresa:

Têm desenvolvido profissionais mais competentes, com visão do negócio, que tem atendimento de qualidade. Garante loja organizada, cliente satisfeito que são atendidos de forma amigável e ágil. Em nossa empresa o clima de trabalho entre os colaboradores também têm influência, acredito que faz parte do Coaching estimular um clima agradável de trabalho, a partir de um bom treinamento e modelos éticos de comportamento exigidos pela a empresa, que se reflete no dia a dia com o cliente na loja. (DADOS DA GERENTE ENTREVISTADA, 2016). 
Nessa sequencia, foi perguntado como costuma destacar a importância do Coaching como reflexo dos resultados da empresa, e a mesma relatou que isso é percebido com o atingimento das metas de vendas nos setores e na venda de serviços ( Seguros) ao cliente, equipe repassando a informação correta no caixa, setor de trocas e crediários, etc.

É papel do Coaching garantir que a informação seja entendida pela a equipe, para que os mesmos criem uma relação de confiança com o cliente. Temos um lema, que é cliente atendido por gente feliz e por um bom profissional compra mais. $\mathrm{Na}$ maioria dos meses neste ano, entregamos bons resultados, isso devido aos profissionais que colocam em prática o que vem aprendendo. (DADOS DA GERENTE ENTREVISTADA, 2016).

No que diz respeito aos resultados e como eles foram medidos, a gerente destacou que foram bem satisfatórios e foram medidos através de relatórios das vendas, do acompanhamento das ações a cada hora, relatou que quando fazem ações de atendimento e focam na venda de um determinado produto, é feito um acompanhamento no dia seguinte e percebe-se o resultado. Além disso, tem a medição do cliente oculto, que acontece a cada dois meses, através dele identifica se os colaboradores estão colocando em prática tudo que aprenderam nos treinamentos ministrados pelo gerente. Nessa perspectiva, indagou-se a gerente se já foi contratado um Coach profissional para treinar a equipe, onde foi respondido que sim. E que a empresa contrata as consultorias especializadas, onde o Coach da mesma, treina o gerente de vendas, que têm o papel de treinar a equipe na sua unidade de atuação. Nesse ponto de vista, perguntou-se também se houve melhorias na capacidade de liderar através do uso dessas técnicas, onde respondeu:

Sim. Uma vez que tenho que desenvolver bons profissionais, também me desenvolvo e cresço a cada dia com as experiências como líder, é isso facilita o meu papel no processo de desenvolver as melhores habilidades e competências de meus liderados. (DADOS DA GERENTE ENTREVISTADA, 2016).

Nessa lógica, perguntou-se sobre a utilização de técnicas do Coaching, se proporcionou uma maior motivação dos colaboradores:

Sim. Já que são instigados a se desenvolver, melhorar seus conhecimentos, traçar objetivos para sua carreira profissional, contribuir com o resultado de uma grande empresa, ser o principal agente de contato com o cliente. Além disso, eles têm a oportunidade de mostrar o seu talento e crescer na empresa, podendo crescer na carreira através da meritocracia, já tivemos muitas promoções para cargos de supervisão e operacional. (DADOS DA GERENTE ENTREVISTADA, 2016). 


\section{Considerações Finais}

O estudo em questão apresentou propósitos, onde, será explicado través dos resultados obtidos. Contudo, pode-se constatar que a utilização de técnicas do processo de Coaching conquista um espaço cada vez maior nas empresas com resultados mais rápidos eficientes e duradouros e no que diz respeito a fatores principalmente como: Equilíbrio entre a vida pessoal e profissional; gerenciamento do tempo; Potencialização das habilidades e maximização dos resultados.

A partir da análise do conteúdo da entrevista e dos questionários realizados, foi possível compreender quais são os principais resultados obtidos pela aplicação do Coaching como ferramenta de liderança nas organizações, assim como, as competências desenvolvidas. Os resultados mostram, em primeira instância que não existe um método padrão para aplicação do mesmo, independente de quem demande a necessidade de aprimoramento.

Percebe-se que a utilização dessas técnicas traz resultados que partem na necessidade pessoal ou profissional das organizações, que contribui como auxilio das habilidades e Potencialização. Observa-se, portanto, que surgem mudanças de comportamento, quebra de paradigmas e limitações como resultados do processo, á medida que também desenvolve o autoconhecimento. Sendo assim, fica mais fácil de compreender de forma clara as oportunidades, ameaças, pontos fortes e fracos da organização e os fatores a desenvolver.

Compreende-se que o Coaching possibilita resultados para a organização e para o indivíduo, o que reflete em uma melhoria principalmente na capacidade de se inter-relacionarem de modo que busquem a perfeição no que desempenhem. Seja na relação entre líderes e liderados, ou questões voltadas à cultura organizacional.

As hipóteses apresentadas como resposta prévia do artigo foram validas e constatou-se que as técnicas de Coaching realmente contribuem com o crescimento dos profissionais envolvidos; eficiência nos processos organizacionais por eles geridos e melhoria dos resultados; melhor produtividade nos setores da empresa; avanço no alcance de metas e resultados; aperfeiçoamento da liderança e gestão por parte dos coordenadores e líderes.

Foi possível constatar que o Coaching aplicado nas organizações ajuda no desenvolvimento das suas competências e melhoria da capacidade traçar metas e estratégias de desenvolvimento.

Os resultados aqui apresentados servem de contribuição para traçar metas e tomar decisões e que estejam interessadas em utilizar técnicas de Coaching para desenvolver seus colaboradores. Considera-se importante também analisar de modo mais profundo os métodos aplicados. Vale salientar que esse processo também auxilia na vida pessoal para ativar a sua capacidade própria, interatividade e autodescoberta, ou seja, ajudar as pessoas a realizar além do que elas pensam que podem. Enfim, a 
abrangência do Coaching com o progresso da capacidade de liderar que a pesquisa ressalta as contribuições de um líder que atua e que deve atuar como Coach.

Sugere-se que este trabalho sirva como fonte de pesquisa para futuros estudos, contribuindo assim para uma análise mais rica dos resultados, a fim de aprofundar ainda mais um assunto tão benéfico as organizações.

\section{Referências}

ALVES, Marcelo Franklin da Silva. O Coaching como diferencial na carreira profissional: um estudo de caso. Disponível em: < www.repositoriobib.ufc.br/000010/00001006.pdf $>$. Acesso em 13 maio 2016

ARAÚJO, Wendel da Silva. Coaching como ferramenta de desenvolvimento da liderança nas organizações. Disponível em:

$<$ http://monografias.ufrn.br/jspui/bitstream/1/672/1/WendellSA_Monografias.pdf $>$ Acesso em 05 mar. 2016.

BERGAMINI, Cecília Whitaker. Liderança: administração do sentido. 2. ed. São Paulo: Atlas, 2009.

BARDIN, L. Análise de Conteúdo. Lisboa, Portugal; Edições 70, LDA, 2009.

CAVALCANTI [et al]. Gestão por competências e gestão do conhecimento. 3. ed. Rio de Janeiro: Editora FGV, 2009.

CERVO, Amado Luiz; BERVIAN, Pedro Alcino. Metodologia Cientifica. 5. ed. São Paulo: Pearson Prentice Hall, 2002.

CHIAVENATO, Idalberto. Construção de talentos. Rio de Janeiro: Elsevier, 2002.

CHIAVENATO, Idalberto. Gerenciando com pessoas: transformando o executivo em um excelente gestor de pessoas. Rio de Janeiro: Elsevier, 2005.

DUTRA, Joel Souza. Gestão de pessoas: modelo, processos, tendências e perspectivas. 1. ed. São Paulo: Atlas, 2009.

GIL, Antonio Carlos. Como elaborar projetos de pesquisa. 5. ed. São Paulo: Atlas, 2010.

GIL, Antonio Carlos. Estudo de caso. São Paulo: Atlas, 2009.

GRAMIGNA, Maria Rita. Modelo de competências e gestão dos talentos. 2. ed. São Paulo: Pearson Prentice Hall, 2007

LAKATOS, Eva Maria. Metodologia Científica. 6. ed. São Paulo: Atlas, 2011.

MARCONI, Marina de Andrade. Metodologia Cientifica: para o curso de direito. 2. ed. São Paulo: 
Atlas, 2001.

OLIVEIRA, Maria Marly. Como fazer pesquisa qualitativa. 2. ed. Petrópolis, Rio Janeiro: Vozes, 2008.

SOUZA, Paulo Roberto Menezes. A nova visão do Coaching na gestão por competências: a integração da estratégia: como desenvolver competências na prática, diminuindo subjetividades e ajustando o foco. Rio de Janeiro: Qualitymark, 2007.

STRAUSS, Anselm; CORBIN, Juliet. Pesquisa qualitativa: técnicas e procedimentos para o desenvolvimento de teoria fundamentada. 2. ed. Porto Alegre: Artmed, 2008.

VERGARA, Sylvia Constant. Projetos e relatórios de pesquisa em administração. 11. ed. São Paulo: Atlas, 2009.

BRASIL. Resolução $\mathbf{n}^{0}$ 510, de 07 DE ABRIL DE 2016. Disponível em: <http://conselho.saude.gov.br/resolucoes/2016/Reso510.pdf > Acesso em: 28 ago de 2016.

Como citar este artigo (Formato ABNT):

LUNA, Matheus de M.; ALMEIDA NETO, José Leandro; MARANHÃO, Thércia Lucena G.; SOUZA, Francisca L.M. O Coaching como ferramenta na formação de liderança nas organizações comerciais: estudo de caso em uma empresa de Juazeiro do Norte. Id on Line Revista Multidisciplinar e de Psicologia, 2017, vol.11, n.37, p. 545-571. ISSN: 1981-1179.

Recebido: 14.09.2017

Aceito: 21.09.2017 